ARTICLE

\title{
Actors in transition: shifting roles in Swedish sustainable housing development
}

\author{
Pernilla Hagbert $^{1}$ (D) Tove Malmqvist $^{2}$
}

Received: 5 March 2018 / Accepted: 29 June 2019 / Published online: 4 July 2019

(c) The Author(s) 2019

\begin{abstract}
In planning for a future that fulfils sustainability goals, there is a need to explore how roles taken in socio-ecological transitions are perceived among different types of actors. Empirical insights from interviews with diverse actors involved in Swedish housing development are presented, addressing the roles, conflicting logics and power relations between different sectoral categories of actors and at different organizational levels. Key aspects that emerge relate to the shift from state to market in contemporary Swedish housing development, where private companies emphasize their role in shaping societal development as inherent to working with sustainability. Conflicting logics can be found between short-term economic interests and long-term planning and policy, as well as intra-organizational differences in competency and leadership. Conclusions point to that the role of third sector or community actors in pushing agendas and norms to bring about transitions could be acknowledged further. Yet there is a need to examine the power relations currently reproduced, and how these could be challenged in future housing development. This includes critically assessing the potential for new types of actors and cross-sectoral collaborations, but also instigating more fundamental discussions of the kind of society strived for, and the radical transitions needed.
\end{abstract}

Keywords Sustainability transitions $\cdot$ Housing development $\cdot$ Multi-actor perspective $\cdot$ Roles

Pernilla Hagbert

pernilla.hagbert@abe.kth.se

Tove Malmqvist

tove.malmqvist@abe.kth.se

1 Division of Urban and Regional Studies, Department of Urban Planning and Environment, KTH Royal Institute of Technology, 10044 Stockholm, Sweden

2 Division of Sustainability Assessment and Management, Department of Sustainable Development, Environmental Sciences and Engineering, KTH Royal Institute of Technology, 10044 Stockholm, Sweden 


\section{Introduction}

Although the direction and extent of transitions to a more sustainable future remains contested, there is nonetheless a growing recognition of the need for more fundamental changes in how society is organized. This includes the design, construction and management of the built environment. Planning for a society that facilitates a safe and just operating space for humanity (Raworth 2012; Rockstrom et al. 2009) is a persistent challenge for policy and practice, not the least in the perception of social and environmental goals and the negotiation of how to reach them. This paper takes a particular interest in what role(s) diverse actors involved in housing development in Sweden-a country often lauded for its ambitious environmental management-perceive they currently have, and could take, in relation to fulfilling far-reaching sustainability goals.

The existing housing stock in Sweden is constituted by $51 \%$ multi-family housing, of which 58\% are rented dwellings (SCB 2019). While a vast majority of single-family homes are privately owned, about $41 \%$ of multi-family buildings are owned by co-operative housing associations (in Swedish called bostadsrätt) —a particular but common form of tenure in Sweden, which combines shared equity and self-management of the property with the possibility for residents to sell their shares at market price, making it a speculative, yet somewhat more collaborative form of housing. Another major actor is municipal housing companies, which own about a third of the multi-family housing stock, with Swedish jointstock companies constituting just over $20 \%$ (ibid.). As pursued in social policies and housing programs throughout the twentieth century, the idea of state-supported housing was seen as synonymous with constructing a Swedish welfare state. However, in what has been described as a neo-liberalization of planning and housing policies in Sweden (Hedin et al. 2011), as in other countries (Beer et al. 2007; Moore and Bunce 2009), the state has rolled back on this publicly-driven housing development. In the last couple of decades, the role of private actors taking a greater environmental and social responsibility has been raised as part of a shift from the strong state to the market (Avelino and Wittmayer 2016; Storbjörk et al. 2018).

Although environmental management has been increasingly institutionalized in the Swedish construction industry over the last few decades (Gluch et al. 2013), the improvements made are however inadequate in meeting for example greenhouse gas emission reduction targets for the built environment (Francart et al. 2018). Previous research has also found interpretations of sustainability in new residential development to be marketoriented and technology-centered (Hagbert et al. 2013), where property developers, even in ambitious frontline projects, are not necessarily pushing the agenda beyond the mainstream (Hagbert and Femenías 2016; Storbjörk et al. 2018). When it comes to aspects of affordability and social justice a more integrated understanding of socio-ecological sustainability remains largely unaddressed, particularly in relation to the environmental implications associated with different residential typologies and household configurations, underlining the need for more nuanced understandings of what type of development is represented as sustainable (Bradley 2009; Mulliner et al. 2013).

While socio-technical dynamics of innovation are well-explored in transition research, recent efforts have more explicitly addressed political dimensions of who the actors involved in sustainability transitions are, the power relations between them, and how these relations and roles might (need to) shift (Avelino and Wittmayer 2016; Kenis et al. 2016). Studies looking specifically at sustainability transitions in relation to the building industry have moreover underlined the "messiness" of transition processes 
(Gibbs and O'Neill 2014) and the heterogenity of stakeholder perspectives (Fastenrath and Braun 2018). This paper contributes to this line of inquiry with new empirical insights, and takes an approach to socio-ecological transitions that underlines the role of different actors in pursuing transformative change towards a more sustainable society. The overarching aim of the study is to explore how diverse actors involved in housing development understand and engage in transitions to reach social and environmental sustainability goals, addressing particular questions of:

1. How do various actors in housing development understand sustainability goals and what role(s) do they perceive they could take in socio-ecological transitions?

2. What potential conflicting power relations and logics emerge in relation to such transitions, and what are the possibilities for shifting these?

\section{Approaching transitions}

\subsection{Towards a sustainable society}

The engagement with and steering towards sustainability has been the interest of diverse research fields, in managing socio-technical innovations (Loorbach 2010); encouraging pro-environmental behaviors and lifestyles (Evans and Abrahamse 2009; Steg and Vlek 2009); or outlining the dynamic role of social practices (Shove and Walker 2010). While relative technological or behavioral changes have been explored to propose different pathways for shifting production and consumptions patterns, a deeper understanding of the energy and material metabolism of modern industrial society (Krausmann et al. 2008) calls for reimagining the framework for-and trajectory to-a future sustainable society altogether.

In what has been described as a 'post-political condition' of sustainability discourse (Swyngedouw 2007), the question of what exactly is to change, and whom should be involved in 'managing' this change (Kenis et al. 2016), is obscured under the guise of concepts of ecological modernization or green growth. Such conceptualizations of sustainability offer a belief in 'smarter' or more efficient ways of design and management, within current market logics (Janković and Bowman 2014). A growing body of critical research however points to the tendency to depoliticize implications of the metabolic flows of modern society (Bradley 2009; Swyngedouw 2007) and the paradox of perpetuating an economic system reliant on growth, based in the exploitation of human and natural resources (Martinez-Alier et al. 2010).

Providing a 'compass' for discussing a future sustainable society, Raworth (2012) proposes a doughnut model outlining a safe and just operating space for humanity that ensures a social foundation while keeping within planetary boundaries (based on among others Rockstrom et al. 2009). The work presented in this paper stems from a trans-disciplinary research program exploring normative back-casting scenarios for a sustainable future Swedish society in 2050, where GDP growth is not seen as a given nor necessarily desired. Four sustainability goals were set up, based in Raworth's integration of social and environmental frameworks (Fauré et al. 2016), serving as illustrations of farreaching goals for a socio-ecological transition: 
1. Climate change: Sweden is fossil-free by 2050 , and GHG emissions are to decrease to maximum 0.82 tons $\mathrm{CO}_{2}$ equivalents consumptive emissions per capita per year.

2. Land use: Land area used for final consumption does not exceed the global bio-capacity of 1.24 global hectares per capita by 2050 .

3. Distribution of Power, Influence and Participation in Society: All residents are entitled to participate in and influence political decision-making that affect their lives.

4. Welfare/Resource Security: All residents should have sufficient access to resources and social services, housing, education, and favorable conditions for good health.

These goals provide an opportunity to envision the future, and entice a discussion on the transitions needed. Exploring what 'life in the doughnut' might mean highlights the complexity in tackling future uncertainties, operationalizing sustainability targets and acknowledging the normative implications of such goals (Fauré 2016), and how they are made sense of among different actors.

\subsection{Actors and roles}

An approach found useful for nuancing the role of different actors in transitions, is the Multiactor Perspective (MaP) proposed by Avelino and Wittmayer (2016). Developed as a response to an identified lack of a structured understanding of actors (and the power relations between them) in sustainability transitions research, the MaP seeks to distinguish between different types of actors, and the level they act on. Avelino and Wittmayer question the equation of power to only certain types of actors, as it tends to overlook for example bottom-up initiatives and civil society actors, and thus also limits possible conceptualizations of transitions as uniform shifts in power. Instead they pose the question of "how different actors exercise different kinds of power at different points in time in different roles" (ibid., p. 633).

The MaP proposes four categories of sectoral actors that build upon a division along axes of formality/informality, for-profit/non-profit, and public/private: the state; the market; the community sector; and the third sector (understood as an intermediary between the others). Recognizing that boundaries are often blurred and contested, sectors should nonetheless be understood as a basis for both struggle and/or cooperation.

Avelino and Wittmayer moreover distinguish three different actor levels: sectors, organizations and individuals. Both individual and organizational actors can operate in different roles and according to different sector logics simultaneously, and roles can also be seen as sites of power and contestation (Avelino and Wittmayer 2016). Recognizing the "political stake of sustainability transitions" (Kenis et al. 2016), for example suggests framing individuals as actors of change in their role as citizens or residents, rather than simply being reduced to consumers within a market logic. Acknowledging a diversity of actors and strategies across different sectorial and spatial contexts (Coenen et al. 2012; Gibbs and O'Neill 2014), this paper focuses on how different sector logics and roles are perceived among various actors involved in housing development, and how power relations might (need to) shift as part socio-ecological transitions of the built environment. 


\section{Research design}

\subsection{Sampling contexts}

The paper is based in qualitative insights from actors related to housing development in Sweden. While limited to a particular national context, it serves as an example of an affluent, high-consuming society often lauded for its environmental management policies, yet with significant challenges in the provision of sustainable living environments. The municipal level has a significant mandate in Swedish planning and building, and the sampling was based on seeking insights from actors operating in local contexts that offer diverse geographical and economic prerequisites, in addition to more general accounts of the conditions for pursuing sustainable housing development in Sweden.

The empirical material was therefore mainly gathered in three different municipal contexts (Fig. 1), that differ significantly in geographical location, population size, the character of the built environment, and the types of actors involved. Övertorneå is often represented as a remote, rural context of economic decline, but is also an interesting premise for understanding how alternative development trajectories might be enacted outside of a prevalent urbanization trend. Alingsås is located in the periphery of the Gothenburg

Fig. 1 Geographical spread of the Swedish municipalities used as a context for sampling

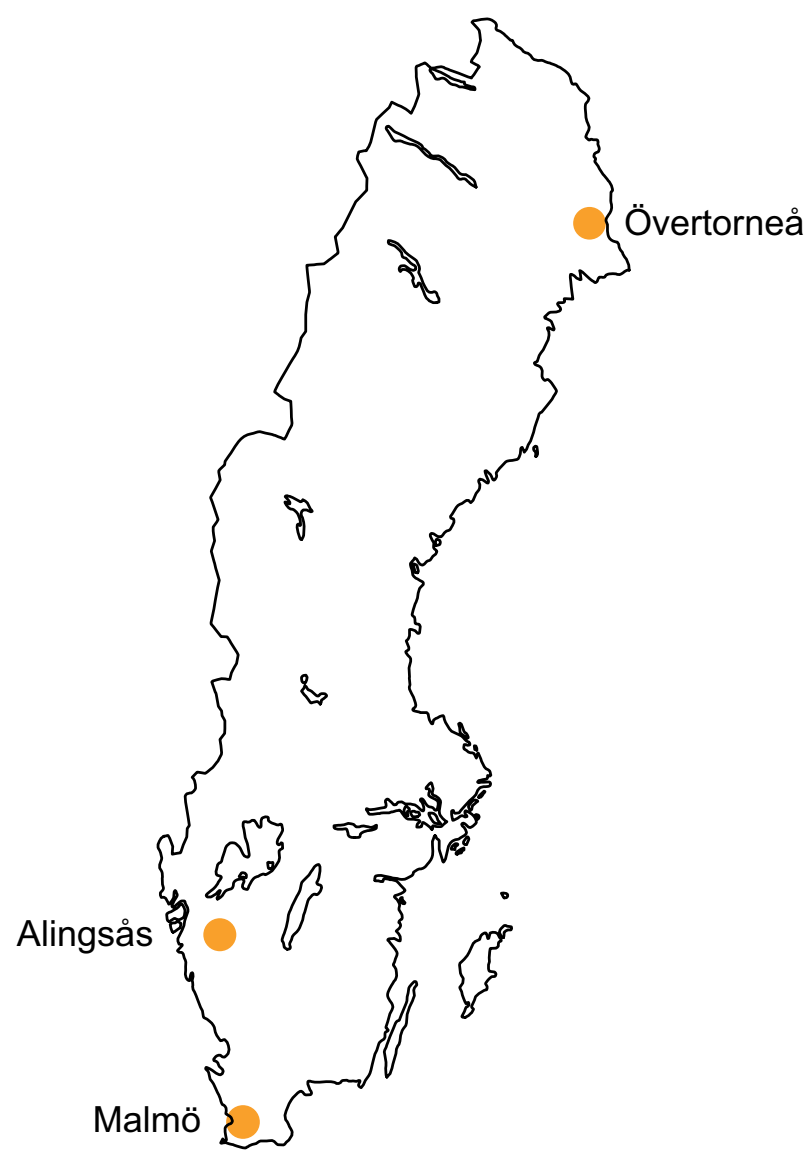


metropolitan region, a semi-rural context with an active local transition movement, and previously home to a center for passive house building. And finally, Malmö, the third largest city in Sweden, poses an example of economic and population growth, yet is also a setting for several ongoing initiatives on for example urban sharing (including among other things tool sharing, car and cargo bike pools, maker spaces and collaborative workshops) and urban agriculture. The local contexts were further complemented by perspectives from actors on a regional and national level.

\subsection{Empirical material}

The empirical material consists of 19 semi-structured interviews with different types of actors involved (directly or indirectly) in the planning, construction and management of residential environments - taking a broad approach to housing development. Sampling was primarily criteria-based, and in some cases complemented by snowballing to reach smaller local actors. As far as possible considering the different contexts, a diversity was sought in relation to the four sectors distinguished in the MaP (Avelino and Wittmayer 2016), as well as with regards to the size and type of the organization, summarized in Table 1. Of interest were individuals that (when applicable in relation to the organization type and size) work with sustainability issues, exploring how those who are professionally tasked to drive the questions view the transition work still to be done.

In addition to market actors, who to a large extent dominate contemporary housing development in Sweden (as reflected in the interviews with in total nine market actors, including two industry federations), perspectives were also gathered from a community actor (a resident in a new co-housing project), a residents' interest organization (third sector), and four state actors in the form of municipal housing companies (one smaller and one large), and county officials working with housing and planning issues in the different geographical contexts. Actors that challenge the sectorial division were also considered of particular interest, including for example co-operative housing companies (bordering between the market and the third sector, in organizing co-operative housing associations and developing new housing on speculation for the interest of their members), a public-private intermediate development association (here considered third sector), and other types of 'emerging' market actors such as a small private consultancy firm working with facilitating co-building projects in the Gothenburg/Alingsås region. Moreover, perceptions among actors that are more indirectly affected by or involved in housing development were explored, including a civil society non-profit organization working with homeless in Malmö, and a local Alingsås based foundation-owned bank, offering complementing perspectives on social and financial implications of housing provision. A limitation of the sampling is that apart from the general restrictions of time and resources for field work, relevant actors from all sector categories were not accessible to the same extent in all contexts. The interviewed actors nonetheless give a variety of perspectives from Swedish housing development, across geographical contexts as well as organizational scale and type.

\subsection{Interviews}

The interviews ranged between 1 and $1.5 \mathrm{~h}$, following a semi-structured interview guide addressing main themes of: how interviewees understand and currently work with sustainability; how they perceive their own role, and that of other actors, in fulfilling ambitious social and environmental goals; and potential conflicts between different interests 


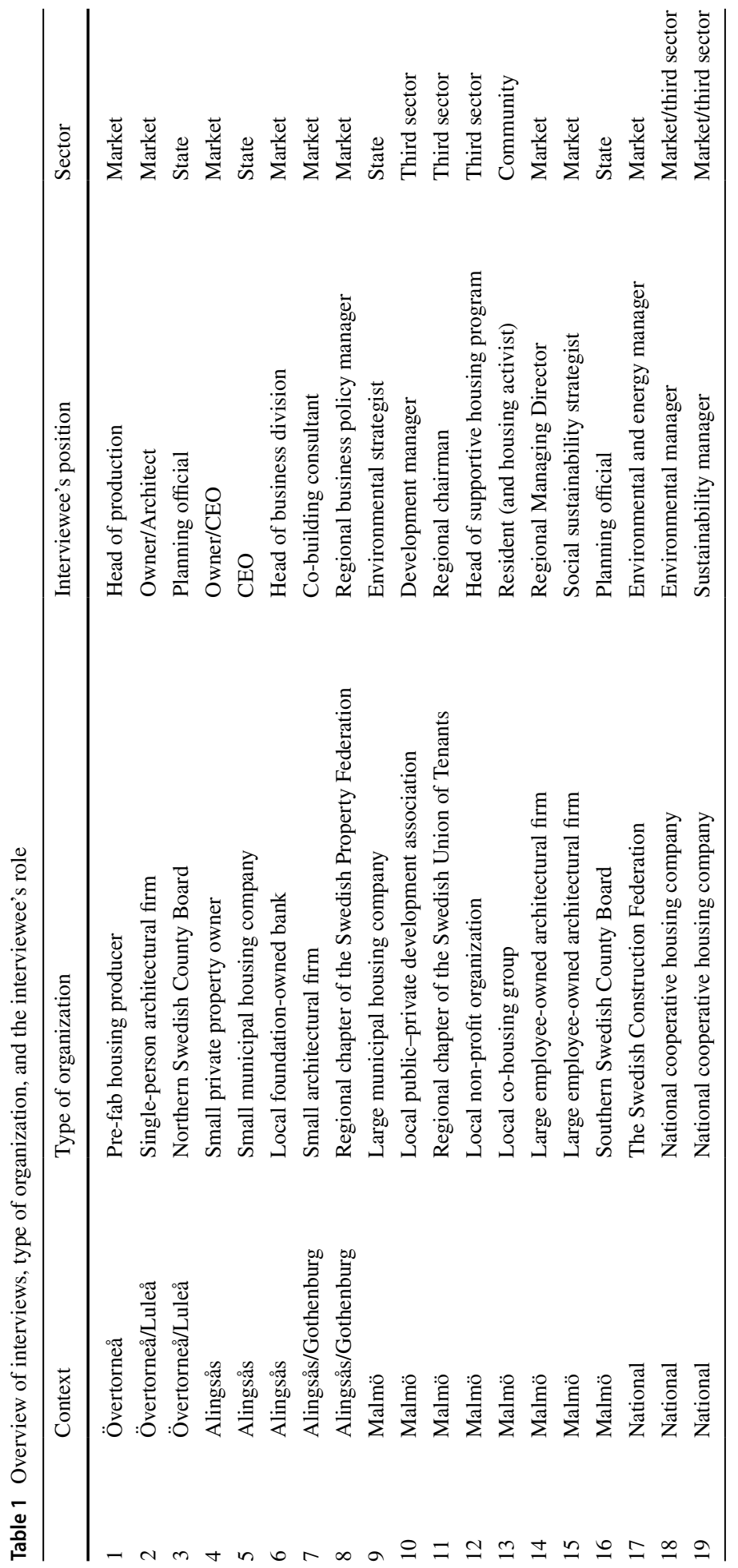


and capacities for engaging in transitions, both in relation to other actors and legislative, infrastructural or social conditions. The interviewees were provided with a summary of the interview guide and the sustainability goals (as outlined above) beforehand. All interviews were recorded and transcribed in full, and analyzed through an iterative process of going back and forth between the questions established at the onset of the study and the emerging themes.

\section{Actors and roles in sustainable housing development}

The results are structured into three parts. The first section addresses the roles different housing development actors perceive they and others should take in reaching social and environmental sustainability goals. The second explores the perceived conflicts that arise between different interests, actor levels and roles. This is then elaborated in a third section on the possibility for shifting roles and power relations within and between actors in pursuing socio-ecological transitions.

\subsection{Actor perspectives on building a sustainable society}

\subsubsection{Who is a 'societal actor'?}

The interviews provide a breadth in perspectives on how different actors approach sustainability goals, both in relation to their specific work, but also how they perceive their role with respect to a sustainable societal development on a more general level. A word reiterated in the interviews is 'samhällsbyggnad' (literally translated as 'society building'), a Swedish term used to signify a holistic concept of (physically and socially) constructing society in a collaborative effort of planning, building and managing the built environment as an assemblage of societal interests and functions. Several of the market actor interviewees describe this 'societal engagement' as going beyond simply constructing or managing properties, to more actively shaping the image of a future sustainable society through influencing what is built and where. The claims made by these actors (dominated by the market sector) in contributing to a sustainable societal development can however also be questioned, as by the social sustainability strategist at a large architecture firm:

I don't think it's societal building [samhällsbyggnad], because... Firstly, they haven't gotten the whole sustainability definition, they base it on themselves. Secondly, they use the parts of sustainability that benefit their own interests, and thirdly, the whole justice perspective is lost, which is a must if you claim to be a societal actor. (Interviewee 15$)$.

Among the co-operative and municipal housing companies, perspectives of participation and welfare are, not surprisingly, more directly described as being at the core, with origins in social and political movements to assure good housing for all during the early twentieth century. The environmental manager at one of the co-operative companies for example describes their history as a "parliamentary democratic" organization that provides "some form of foundation for participation" to build upon further, as part of a sustainable housing development. The same interviewee however stresses that the current demographic make-up of their member base does not necessarily represent Swedish society for example when it comes to average income or age, which leads to the question of: "well, should we 
do what our members want, or should we do what we know are the larger needs of society?" (Interviewee 18).

The sustainability goal of distribution of power, influence and participation, is described by several of the interviewees as a key challenge for housing provision. As expressed by the CEO of a small municipal housing company, this could for example mean working with the perspective of residents' "right to decide in matters regarding their own life", regardless of socio-economic situation, age, or ability (Interviewee 5). Or as the environmental strategist at another municipal housing company describes their role in providing a 'public good' (in Swedish 'allmännytta'), connecting also to the second social goal on welfare:

In our form and our ownership structure we have a mandate to in a way, per definition, act for the good of the public. And that's mainly about housing provision. /.../ And right now the housing shortage is a huge sustainability challenge, among many. (Interviewee 9).

The ability of public actors to provide adequate housing can nonetheless also be contrasted with the perspective of an interviewee working with a non-profit supportive housing program for homeless, who sees their role as:

... a complement to the municipality, the state, but we are not just a complement. Instead we rather we go in where we see needs and shortcomings, and try to support /.../ these people that otherwise fall between the cracks in the system, that might not be eligible for care, but that also can't manage housing completely on their own. (Interviewee 12).

\subsubsection{Who drives sustainability issues?}

While there appears to be a common perception among interviewees that the housing industry as a whole has come far in both acknowledging and actually working with sustainability over the course of the last decade, it is still fragmented, both with regards to environmental goals relating to for example energy and materials, and largely lacking when it comes to social aspects. A reason offered by several interviewees is that 'regular' residents (understood as those not choosing to reside in urban eco-districts), framed as consumers within a market logic, are not always asking for more sustainable alternatives. Still, this is also described as changing, where for example the regional managing director at a large employee-owned architectural firm (Interviewee 14) talks about how environmental sustainability (understood mainly in eco-efficient terms) is becoming a basic 'hygiene factor' in all projects, both from the perspective of developers and consumers.

A more nuanced understanding of 'civil society' or 'community' sectors in transitions however challenges the story of housing as a product that can be more or less 'green'. Emphasizing the relationship with tenants as key, a private, small-scale property owner (Interviewee 4), describes working with sustainability in a way that is made possible precisely because of an engagement at the individual actor level, as part of a local context. While more reactive than innovative, this approach is based in an openness to facilitating resident initiatives, rather than pushing certain technical solutions or concepts. In this sense, bottom-up calls for less environmentally impactful and more socially just ways of living might not always be as formalized. They could take shape within a specific community, that in turn can grow to gain more formal influence. A resident (who also identifies as a housing activist) in a relatively new urban co-housing project reflects on the role resident communities could have in driving change vis-à-vis incumbent actors: 
I think that for the people that live here, it creates some sort of critical mass, where you can start testing things, you can push norms because you're not alone./.../ And if we talk large companies versus small, we were considered by the municipal housing company to have a lot of power. Despite that we weren't legally binding or had put in any money, we were an important stakeholder. (Interviewee 13).

The role of more formalized third sector actors is also raised in the interviews. The chairman of a regional chapter of the tenants' association for example talks about returning to the strong position they once held in order to put pressure on housing companies to build affordable and with lower environmental impact, and discuss what kind of society we want:

Where we were 40 years ago, when we were part in demanding, as part of the societal debate, how we build, where we build, and so on, that's where we are going to go now, partly to show we take a greater responsibility. (Interviewee 11).

\subsection{Conflicting logics between sectors and actor levels}

\subsubsection{Negotiating market logics in long-term planning}

Both public and private actor interviewees frame sustainability in business-terms. Simply put: making money on being greener or more efficient, or in the promise of "decoupling business from resource use... well high resource use anyways", as expressed by the environmental manager at a large municipal housing company (interviewee 9). The two trade organizations interviewed, representing market interest while themselves not operating within a for-profit logic, are primarily lobbying for the interests of their member companies, and as explained by the environmental and energy manager at the Swedish construction federation:

How we work today is to influence the conditions, that is, rigging the framework so that it's easy and profitable for the construction companies to work sustainably. (Interviewee 17).

As part of market actors taking on a more significant role in rigging the conditions, there is also a perceived need to mediate between different sector logics in order to steer devel-

opment. The regional business policy manager from the Swedish property federation for example emphasizes their role in pushing the agenda:

The property owners and the municipality don't always understand each other and haven't found each other in a dialogue regarding how society should be developed, and there I try to be some sort of glue in-between and get them to talk to each other. (Interviewee 8).

What is implied is translating business interests into societal interests, and vice versa. This however also raises a question of whether merging state and market logics is actually blurring perspectives, expressed by the co-housing resident and activist:

I definitely think there's a blindness in that there are different perspectives, that you have different agendas, that municipalities many times are too blue-eyed in that case and only believe in win-win everywhere. (Interviewee 13).

Almost all interviewees point to the negotiation between a prevailing profit-maximizing perspective in contemporary housing development, and visions for a more sustainable 
society. The interviewed planning officials working in Sweden's most northern and most southern counties respectively, point to issues relating to the pressures from short-term interests that do not consider long-term consequences on land use. An example brought up is the conflict between continued growth of urban areas, and the need to preserve some of Europe's highest quality farmlands located in southern Sweden. And in a more sparsely populated context, the northern county planning official raises similar aspects of food security and self-sufficiency in the negotiation between vested interests in northern natural resource exploitation (such as mining and forestry), residential and infrastructure development, and food production. This is further elaborated by a self-employed architectural consultant working in the region, who describes the conflict in adhering to a dominant economic logic:

When it comes down to it, it's always a special interest /.../ these large economic interests, they always come before other interests. You don't make a value assessment. If you did an external assessment and let economic interests be on par with social values, or ecological sustainability values, it would be a different thing. (Interviewee 2).

The county administrative boards hold a regulatory position in representing the state and following up to make sure regional and national goals are implemented in local planning. With the strong municipal mandate in land use planning in Sweden, the local building committees are in turn perceived by one of the county planning officials to "have all the responsibility and all the possibilities" (Interviewee 3 ). Yet, in practice, the politicians in small municipalities are perceived to have a quite weak role in enacting for example more ambitious local environmental policies in the face of economic pressure:

The municipality is afraid that the actors won't want to build anything if you don't lower the requirements. But if all municipalities would have the same requirements, if they would dare to band together, then you can't go elsewhere if you want to build. It's like the construction industry runs this divide and conquer technique against municipalities with small resources. (Interviewee 3).

This can be contrasted by the way market actors talk about the legislative conditions for reaching social and environmental sustainability goals, where there has been and is still an intense debate on the role of local environmental targets. Whereas some market actor interviewees (particularly the Swedish Construction Federation) reiterate their position on the preference for more general national policies in order to streamline their work, the sustainability manager at one of the co-operative companies underlines the important role of municipalities in bringing these issues to the top of the agenda, to help push sustainability within the companies:

I wear two hats of course, wanting a uniform production to be able to proceed with my implemented ways of working. But at the same time, it's been super important for us - sustainability wise - to have special requirements from the municipalities. Because that's been the propelling force for us. (Interviewee 19).

While the lobbying for market interests might be persistent, the need for clearer political positioning and a political debate (in a sense solidifying rather than blurring state logics) is at the same brought up by interviewees from all sectors. The interviewees want a better outline of the 'playing-field' - the inter-sector logics they have to relate to in framing their work towards a sustainable housing development. Several say that they welcome stricter legislation, but stress that this should not be restricted to a certain technology or solution, 
which might lead to lock-ins based on current technological trends and undermine their competency in coming up with diverse ways of defining and tackling the problems at hand.

\subsubsection{Intra-organizational differences}

The generally positive attitude among interviewees towards introducing stricter legislation, it should be noted, is most likely linked to the individual roles of the interviewees. They might operate according to multiple logics, in for example working in a for-profit organization, while holding a position as environmental or sustainability manager, with a selfdescribed passion for working with sustainability perspectives-and perhaps more importantly, a knowledge of issues of climate change or social justice. Here the individual actor role within the organization might follow different logics than the organizational level. Interviewees point to trying to challenge dominant market sector logics of for example how you valuate the business, quarterly reporting, or who is represented in the leadership at the companies, and the conflicting perspectives that might exist. There is a common perception that as long as sustainability issues are not addressed at the top level, they will remain secondary to a 'business-as-usual' approach. The importance of competency and education about social and environmental issues is highlighted, as elaborated by an interviewee who contrasts their perspective as an environmental manager with that of the company's leadership group:

It's economists, controllers, that are [in the leadership]. And they will... they are starting to get a deeper understanding, but it's still very shallow. And that has to do with the whole educational system. That you can go through an education without having to think about resource issues or equality matters. (Interviewee 18).

The sustainability manager at one of the co-operatives, the only one among the interviewees in a similar professional position who has gotten into the leadership group, describes the struggle it took to get there, but also the difference it makes when the issues are considered relevant enough to be included at the highest level. While an awareness might be starting to permeate the organizational practice in some companies, there is nevertheless also a described lack of competency in the industry as a whole, coupled with a slow turnover from a (male-dominated, conservative) business culture, forming a regime reluctant to change, as underlined also by the environmental and energy manager at the Swedish construction federation:

You think they [the leadership] will be replaced, but it's still this group that selects the new, and if they don't understand the issues, they won't select... so it is a bit selfcementing. (Interviewee 17).

\subsection{Barriers and possibilities for shifting roles}

The final aspect of the empirical findings in relation to the research questions addresses how interviewees perceive transitions as suggesting more or less radical shifts in terms of the possibility for new roles and relations between actors. The various strategies raised in the interviews imply changes ranging from company forms and new types of collaborations, to renegotiating key concepts for how to operate within, across or beyond sectoral boundaries, and the need for exploring what power relations are enforced or challenged. 
The need for significant transitions, at a faster rate and larger scale than what is currently being done in Swedish housing development is underlined throughout the interviews. Yet as expressed by the environmental manager at a large municipal housing company, when reflecting on the potential for change within the current regime:

It doesn't seem likely that these subversive societal changes, that are of this kind, will come... like there might be societal changes, but they are... well we have a pretty self-preserving system. (Interviewee 9).

The potential for finding new ways of working, new company forms and constellations of actors is not obvious to all interviewees, but especially intermediary actors, or those trying to find a more cross-sectoral approach between conventional sector logics, provide some insights into what new relations could be formed as part of transitions. The municipally employed development manager at a local development association-consisting of property owners, housing associations, businesses and other local interest groupsdescribes the role of connecting perspectives and people to incite new ways of thinking and working with sustainable urban development as locally based and dependent on different actors pledging a shared commitment:

The partnership is the overarching role, that we create a partnership between civil society, the private and the public. And these three parties need to be able to sit down and discuss these questions, and we also need to be able to sit and find solutions. (Interviewee 10).

Here, the formation and maintenance of networks — both formal and more informalis pointed out as a key element in bringing together for example market or state actors with civil society and marginalized community groups to create opportunities for increased social cohesion and improved environmental management in housing areas. When it comes to practice, however, the development association in question has nonetheless been criticized for being too market-oriented, missing alternative local community perspectives, as expressed by the co-housing resident who lives in the area, and who sees the need for other bottom-up platforms for people to engage in questions of justice and sustainable urban development.

An example of a 'new' form of business trying to negotiate what it means to be a market actor is given by a consultant at a smaller architectural firm, working with facilitating co-building projects as a way to increase residents' influence and engagement with sustainable living environments, and challenging the current limitations in housing provision (and their own role as consultants). Although still operating within a for-profit framework, the company is by the interviewee perceived as a different type of actor, trying to work in ways that differ from the established logic of a consultancy firm. An example is that $10 \%$ of employee time is devoted to self-development, to enable reflection and activities "not only to make money on" (Interviewee 7).

While co-operatives or employee-owned companies are often 'idea-driven businesses', smaller private companies can also, due to their organizational nature, be based in the particular ideas of the owner(s), although the founding values might not always be as explicit. The small-scale property owner interviewed, for example, emphasizes several times that business-wise, it is smarter to build apartments to sell, not work with long-term property management in a semi-rural municipality. Still, the interviewee expresses being content keeping the company small and making investments at a steady, 'responsible' rate. In contrast, larger publicly traded companies have a very different premise for operating, with an expectation from stockholders to maximize return on investment. 
A key concept-with relevance for how actor relations are shaped-raised in the interviews is the notion of 'good business', where short-term profits are weighed against building long-term relationships that provide a mutual basis for negotiating and working on implementing change. Here, it seems that while most interviewees agree that a profitmaximizing market logic is dominant in current understandings of housing development, this is not a given. By negotiating what constitutes good business from a more socio-ecological perspective, but also an economic resource management view-beyond a speculative financialization of housing - some, like the CEO of the small municipal company, see opportunities to formulate a new framework:

If you look at it, we can contribute to each other instead of someone taking over and making a profit on someone else. You can't maximize, you can't line your own pockets to the detriment of someone else, because then there is no sustainable business. (Interviewee 5).

The interviews point to the potential in renegotiating actor relationships in order to find new ways of working beyond current lock-ins and established roles. What this would mean for questions of power (challenging current power relationships or reproducing them) and knowledge claims (including who is regarded a knowledgeable actor) is however less clear. The environmental and energy manager at the Swedish Construction Federation for example suggests that there needs to be a further shift towards seeing construction companies as not only performing pre-formulated tasks from a construction client, but also in defining the task, and hence the solution(s) as a more collaborative challenge. This is in line with the reasoning behind 'partnering', where actors from public and private sectors share the stakes-although not necessarily the risks-in new projects.

Exemplified in the interviews, a narrative of innovation is framed as giving the market freedom to self-improve through voluntary certification programs, along with setting ambitious albeit broad national policy targets. The idea is that market actors will be able to produce more efficient and 'appropriate' built environments if they don't have to adapt to specific local regulations or detailed demands from clients that might not necessarily be knowledgeable enough to know what to ask for. This view, as described by several of the market actor interviewees, however assumes that incremental improvements are enough, and does not propose ways of working with more fundamental transitions. Another narrative of collaboration found in the interviews that might drive the development further in reaching sustainability goals, is for state, third sector, and community actors to gain a better insight into the implications of different solutions and development trajectories. As expressed by the co-housing resident, this means acknowledging existing power relations, knowledge mandates and gaps among incumbents in Swedish housing provision, and supporting other actors in "their capacity as residents and citizens and associations, who are not the ones who hold all the money and power today". (Interviewee 13).

\section{Concluding discussion}

This paper discusses the implications of who will drive transitions to a socially just housing development within planetary boundaries. The presented interview study with diverse actors involved in Swedish housing development addresses the roles, conflicting logics and power relations, and the empirical insights point to several significant challenges in approaching transitions to meet far-reaching social and environmental goals. 
The perceived roles that different actors report taking, or imagine they could take in working towards fulfilling sustainability goals, firstly need to be related to the construct of responsibilities assumed to go with certain roles. As raised by Avelino and Wittmayer (2016), a critical point is who can afford to take risks in engaging in transformative activities, and what new dependencies between sectors and different actors that might appear. A key question that emerges is who bears responsibility for ensuring a housing development that meets far-reaching social and environmental sustainability goals such as those set as the premise for this paper, where for example access to housing in itself is formulated as part of a social goal of resource and welfare security.

In mainstream sustainability transition narratives, which tend to depoliticize (Kenis et al. 2016) or lack a more systematic and explicit analysis of the constructed roles of different sectors and actors (Avelino and Wittmayer 2016), the market is often assumed to take lead, through incremental yet (technologically) significant advances. This is a trend in many liberal countries, but is perhaps particularly noticeable in a context like Sweden, which has gone from being characterized by a strong state-driven housing development to a rather rapid neo-liberalization of housing since the 1990s. The interviews underline this shift from state to market actors driving contemporary Swedish housing development, where private companies emphasize their role in shaping societal development as inherent to working with sustainability. Whether this will be enough to change the direction from an unsustainable path dependency to a development that enables reaching sustainability goals is debated, particularly if this incrementalism fails to challenge dominant logics and shortterm market interests in relation to the commitments and long-term perspectives needed to plan for a sustainable future. Similar to what has been concluded in previous studies on Swedish developers' response to climate change in planning (Storbjörk et al. 2018), the interviews point to the dual role of regulation, in that interviewees acknowledge the need for clear and ambitious requirements to push the market forward, but at the same time see it as problematic from the perspective of streamlining production.

In the negotiation between individual, organizational and sectoral actor levels, the empirical insights points to a need to understand the roles different actors hold, and the associated power or mandate this entails. The interviewees shift between different roles and different logics as part of their everyday life: they are residents, neighbors, as well as professionals. Some share more similarities than differences in their professional background and role as environmental or sustainability managers, regardless of working within the state or market sector. This is evident in their relationships with the leadership in the respective organization-whether as for the municipal housing companies, where interviewees seek clearer local political leadership, or in many of the private companies, where interviewees describe the gap in competency on sustainability issues in the executive management. The possibility of gaining inspiration from networks to push change beyond the individual professional role is raised, yet the role of industry-led initiatives such as for example the Sweden Green Building Council in driving change is both lauded and questioned in the interviews.

To adopt new strategies that go beyond business-as-usual, an understanding of socioecological transitions will need to permeate the organizations. The interviewees point to the role of education more broadly, not only among the professions 'directly involved' (such as planners, architects, engineers) who have already seen an —at least initial—shift in how sustainability is integrated into the professional role, but also among managers, economists and lawyers who hold key decision-making roles in housing development. Beyond relying on education to shape future business culture, however, the interviews point to that the 'rules of the game' will also need to be challenged, raising questions of organizational 
leadership, financial and accounting policies. A particular issue is the notion of the market as a 'societal' actor, especially among those who question whether a marketization of housing is compatible with a social justice framing of housing as a human right.

The range of actors interviewed nonetheless provide an essential perspective on the need to nuance understandings of organizational and individual actors also within sectors such as the 'market'. This supports conclusions from previous studies on sustainability transitions in 'green building', that underline that the actors driving change might not belong to a neatly defined category (Gibbs and O'Neill 2014) or share a homogenous interest (Fastenrath and Braun 2018). The interview insights hint at different market actors having different starting points for engaging in transitions. This can be linked to an ongoing discussion in Sweden regarding the need for improved tools for policy and planning to encourage and enable for example smaller actors, believed to increase innovation and a diversity in responses to social and environmental challenges. While smaller companies might be in a position to operate according to slightly different logics than large publicly traded corporations, it is only true to a certain extent. They are still limited by the same overarching structures of formal planning procedures, a paradigm of economic growth, and a rigid financial system dictating what investments are deemed profitable or not.

Sweden has a rather unique history of large co-operative housing companies developing explorative projects, and with such a large share of multi-family housing being owned by co-operative housing associations, the national organizations could have a significant role as potential forerunners in pushing the development further. Despite their origins, however, they today also largely operate within the for-profit logic of the housing market, while at the same time having to tackle the challenge of representing member interests in relation to societal needs at large. Other types of actors, from the community or third sector, have not been as prevalent in Swedish housing development during the last decades, compared to the civil society involvement in housing in for example Germany or other countries. One example is that co-building initiatives, or baugemeinschaft as it is called in German, where residents go together to commission a new residential development, is a rather new (and increasingly discussed) phenomenon in Sweden. Cooperative rental solutions, which also exist in many other countries, are still rare, yet provide another promising alternative. Such actor constellations could potentially contribute to pushing a transitions agenda further, as these types of 'bottom-up', grassroots perspectives exemplified in co-building, self-build or co-housing groups are often lauded as innovative low-impact developments (Pickerill and Maxey 2009; Seyfang and Smith 2007). Yet a critical question is whether such idea-driven initiatives will be enough, and proponents often underline that they do not replace the need for a political discourse and broader public response-which is also stressed by the cohousing resident/housing activist interviewed.

While the Swedish housing context might differ somewhat from other European countries, the current situation has similarities with other contexts that can be understood within the neo-liberalization of planning and housing development across Europe and elsewhere. The role of public actors in this development, according to interviewees, will be dependent on the political will and consistency of national as well as local sustainability visions and housing policies. Municipal housing companies could lead the way in exploring affordable, low-impact building principles and enabling alternative everyday practices, but are currently also restricted by for example a new law from 2011, mandating that they should act 'business-like' to equalize competition between private property owners and municipal companies. Along with other national legislation regarding subsidies, investments and tenure form, this new regulatory framework challenges sectoral boundaries and the "common good' logic municipal-driven housing provision has previously operated within. 
Beyond a regulatory capacity (including taxation and other monitoring imperatives associated with the state), planning could hold a clearer role in pushing the market, but also enabling community or third sector actors to not only take part, but potentially lead new collaborations and developments centered in social justice, ecological stewardship and post-carbon ways of living. From the perspectives raised in the interviews, it is however clear that such initiatives are dependent on competent and engaged people with the mandate to actually act-sometimes despite prevailing logics. While the role of third sector and community actors in pushing agendas and norms to bring about transitions need to be acknowledged in future housing development, it appears critical to examine the power relations reproduced, particularly with regards to whose voice is recognized and in what capacity different actors are included.

In conclusion, the formulation and critical examination of sustainability goals can offer a platform for discussing different development trajectories, but a more fundamental discussion of the kind of society strived for also means recognizing the mediation between a social foundation and planetary boundaries as inherently political. As expressed by a market sector interviewee: 'businesses adapt', but to be able to adapt there needs to be a clear goal definition and an idea of what kind of future we as a society want to move towards. Considering housing provision as a complex societal challenge with a large socio-ecological impact, an objective might not be to seek consensus on a single concept or assign a particular type of actor to take lead. Rather, future research and policy will need to nuance and acknowledge a pluralism in perspectives, and the possibility for different actors to be involved in discussing and pursuing normative socio-ecological goals and transitions.

Acknowledgements Open access funding provided by KTH Royal Institute of Technology, Stockholm. Funding for the study was provided by the Swedish research council Formas (Grant No. 2013-1842).

Open Access This article is distributed under the terms of the Creative Commons Attribution 4.0 International License (http://creativecommons.org/licenses/by/4.0/), which permits unrestricted use, distribution, and reproduction in any medium, provided you give appropriate credit to the original author(s) and the source, provide a link to the Creative Commons license, and indicate if changes were made.

\section{References}

Avelino, F., \& Wittmayer, J. M. (2016). Shifting power relations in sustainability transitions: A multi-actor perspective. Journal of Environmental Policy \& Planning, 18(5), 628-649.

Beer, A., Kearins, B., \& Pieters, H. (2007). Housing affordability and planning in Australia: The challenge of policy under neo-liberalism. Housing Studies, 22(1), 11-24.

Bradley, K. (2009). Just environments: Politicising sustainable urban development. (PhD thesis). KTH Royal Institute of Technology, Stockholm.

Coenen, L., Benneworth, P., \& Truffer, B. (2012). Toward a spatial perspective on sustainability transitions. Research Policy, 41(6), 968-979.

Evans, D., \& Abrahamse, W. (2009). Beyond rhetoric: The possibilities of and for 'sustainable lifestyles'. Environmental Politics, 18(4), 486-502.

Fastenrath, S., \& Braun, B. (2018). Ambivalent urban sustainability transitions: Insights from Brisbane's building sector. Journal of Cleaner Production, 176, 581-589.

Fauré, E. (2016). Sustainability goals combining social and environmental aspects. (Licentiate thesis). KTH Royal Institute of Technology, Stockholm.

Fauré, E., Svenfelt, Å., Finnveden, G., \& Hornborg, A. (2016). Four sustainability goals in a Swedish lowgrowth/degrowth context. Sustainability, 8(11), 1080.

Francart, N., Malmqvist, T., \& Hagbert, P. (2018). Climate target fulfilment in scenarios for a sustainable Swedish built environment beyond growth. Futures, 98, 1-18. 
Gibbs, D., \& O’Neill, K. (2014). Rethinking Sociotechnical transitions and green entrepreneurship: The potential for transformative change in the green building sector. Environment and Planning A: Economy and Space, 46(5), 1088-1107.

Gluch, P., Gustafsson, M., Thuvander, L., \& Baumann, H. (2013). Charting corporate greening: Environmental management trends in Sweden. Building Research \& Information, 42(3), 318-329.

Hagbert, P., \& Femenías, P. (2016). Sustainable homes, or simply energy-efficient buildings? Journal of Housing and the Built Environment, 31(1), 1-17.

Hagbert, P., Mangold, M., \& Femenías, P. (2013). Paradoxes and possibilities for a 'Green' housing sector: A Swedish case. Sustainability, 5(5), 2018-2035.

Hedin, K., Clark, E., Lundholm, E., \& Malmberg, G. (2011). Neoliberalization of housing in Sweden: Gentrification, filtering, and social polarization. Annals of the Association of American Geographers, 102(2), 443-463.

Janković, V., \& Bowman, A. (2014). After the green gold rush: The construction of climate change as a market transition. Economy and Society, 43(2), 233-259.

Kenis, A., Bono, F., \& Mathijs, E. (2016). Unravelling the (post-)political in transition management: Interrogating pathways towards sustainable change. Journal of Environmental Policy \& Planning, 18(5), 568-584.

Krausmann, F., Fischer-Kowalski, M., Schandl, H., \& Eisenmenger, N. (2008). The global sociometabolic transition. Journal of Industrial Ecology, 12(5-6), 637-656.

Loorbach, D. (2010). Transition management for sustainable development: A prescriptive. ComplexityBased Governance Framework. Governance, 23(1), 161-183.

Martinez-Alier, J., Kallis, G., Veuthey, S., Walter, M., \& Temper, L. (2010). Social metabolism, ecological distribution conflicts, and valuation languages. Ecological Economics, 70(2), 153-158.

Moore, S., \& Bunce, S. (2009). Delivering sustainable buildings and communities: Eclipsing social concerns through private sector-led urban regeneration and development. Local Environment, 14(7), 601-606.

Mulliner, E., Smallbone, K., \& Maliene, V. (2013). An assessment of sustainable housing affordability using a multiple criteria decision making method. Omega, 41(2), 270-279.

Pickerill, J., \& Maxey, L. (2009). Geographies of sustainability: Low impact developments and radical spaces of innovation. Geography Compass, 3(4), 1515-1539.

Raworth, K. (2012). A safe and just space for humanity. Can we live within the doughnut? Oxfam Discussion Papers. Oxfam, Oxford.

Rockstrom, J., Steffen, W., Noone, K., Persson, A., Chapin, F. S., Lambin, E. F., et al. (2009). A safe operating space for humanity. Nature, 461(7263), 472-475.

SCB. (2019). Dwelling stock. Statistical news from Statistics Sweden. From https://www.scb.se/. Retrieved June 19, 2019.

Seyfang, G., \& Smith, A. (2007). Grassroots innovations for sustainable development: Towards a new research and policy agenda. Environmental Politics, 16(4), 584-603.

Shove, E., \& Walker, G. (2010). Governing transitions in the sustainability of everyday life. Research Policy, 39(4), 471-476.

Steg, L., \& Vlek, C. (2009). Encouraging pro-environmental behaviour: An integrative review and research agenda. Journal of Environmental Psychology, 29(3), 309-317.

Storbjörk, S., Hjerpe, M., \& Isaksson, K. (2018). 'We cannot be at the forefront, changing society': Exploring how Swedish property developers respond to climate change in urban planning. Journal of Environmental Policy \& Planning, 20(1), 81-95.

Swyngedouw, E. (2007). Impossible 'Sustainability' and the Postpolitical Condition. In R. Krueger \& D. Gibbs (Eds.), The sustainable development paradox: Urban political economy in the United States and Europe (pp. 13-40). New York: Guilford Press.

Publisher's Note Springer Nature remains neutral with regard to jurisdictional claims in published maps and institutional affiliations. 